\title{
Human Resource Management Practices: Influence of recruitment and selection, and training and development on the organizational performance of the Jordanian Public University
}

\author{
${ }^{1}$ Saifalislam, K. M., ${ }^{2}$ Osman, A \& ${ }^{3}$ AlQudah, M.K \\ ${ }^{123}$ School of Business Innovation and Technopreneurship, University Malaysia Perlis (UniMAP)
}

\begin{abstract}
This study examines the impact of Human Resource Management (HRM) practices as well as the factors that affect recruitment and selection as well as training and development onthe organization performance of the Jordanian Public University in the Kingdom of Jordan. The sample comprises staff and lecturers of the university. To achieve the study objectives, the researchers developed a questionnaire, which was administered in a survey. The collected data were analyzed by using SPSS. The analysis of the descriptive statistics and correlations indicated that recruitment and selection as well as training and development significantly correlated with the organizational performance of the Jordanian Public University. The study also recommended the steps to improve HRM practices in the university.
\end{abstract}

Keywords: recruitment \& selection, training \& development, organizational performance

\section{Introduction}

Human resource management (HRM) refers to the practices, systems, and policies that influence the behavior, performance, and attitudes of employees (De Cieri et al., 2008). Human resource practices include selecting human resource needs, screening, recruiting, training, rewarding, appraising as well as attending to labor relations, safety and health, and fairness concerns (Dessler, 2007). The recent years has shown a growing interest in the management of knowledge-based organizations (Robertson\& Swan, 2004). The effective implementation of HR practices in organizations is a key source of competitive advantage and has a positive relationship with organization performance (Collins, 2007). Studying topics of modern management, which includes recruitment and selection, training and development and the factors affecting the practice, is a new concept to developing countries, such as Jordan. Hence, the study of this subject in this context adds to the significance of this research, which also considers technological and economic circumstances and variables. The multi-policy, as practiced in the Jordanian private sector, requires the adoption of the concept of recruitment, and the selection and training and development from the perspective of the applicants. Such practice will keep up with the rapid environmental changes.

\section{Organization performance}

One of the main discussions in this study focuses on the determinants of organization performance. Scholars from different backgrounds have explained organization performance and identified the sources of inter-organization performance differences (McGahan\& Porter, 1997). Organization performance is determined by measuring the actual outputs of an organization against its intended outputs (i.e., goals or objectives). According to Richard, Devinney, Yip, \&Johnson (2009), organization performance comprises three areas of company outcomes, namely, financial performance (return on assets, return on investment, and profits), product market performance (sales and market share), and shareholder return. Organization performance also refers to strategic planning, operations, finance, legal, and organization developments. Several researchers relate organization performance to financial performance, which involves budgets, assets, operations, products, services, and markets (Thurbin, 1994; Smith, 1999; Subramaniam, Shamsudin, \& Ibrahim, 2011; Dixon, 1991).Some researchers identify several non-financial outputs that also contribute to organization performance, namely, management quality (De Waal \&Frijns, 2011), long-term orientation (Steiss, 2003; Guest, 1997), continuous improvement (Arsad, 2012), workforce quality (Storey, 1989), and openness and action orientation (Pathak et al., 2005). In this study, the researchers examined the organization performance via management and workforce qualities.

\subsection{Recruitment and selection}

Recruitment is the process of gathering qualified applicants for available positions within an organization (Mathis, 2004), and deciding whether to employ the qualified applicants or to reject them. Selection involves choosing the most suitable applicants who satisfy the requirements for a particular job. The practice of selection is a decision-making activity or a psychological calculation of appropriateness (Price, 
Human Resource Management Practices: Influence of recruitment and selection, and training .....

2004). Organizations that adopt appropriate selection processes are guaranteed to hire employees with the right skills and levels of confidence for a particular job (Pfeffer, 1994; Huselid, 1997). Some researchers found that prerogative recruitment and selection practices positively affect organizational performance (Harel \& Tzafrir, 1996; Delany \& Huselid, 1996). Delary and Huselid (1996) found that effective recruitment and selection processes positively affect organization performance. By studying the employee recruitment, retention, and performance strategies in the Nigerian civil service, Gberevbie (2010) emphasized the importance of adopting appropriate employee recruitment and retention strategies to improve organizational performance. Other researchers suggested that a significant and positive relationship exists between recruitment/selection and organization performance (Terpstra \& Rozell, 1993; Harel \& Tzafrir, 1996; Gberevbie, 2010).

\subsection{Training and development}

Training and development is an important element of HRM (Vlachos, 2009). Organizational performance may benefit from training and development in several ways (Subramaniam et al., 2011). Training is a marshaled activity that aims to impart instructions or information to improve the performance, knowledge, or skills of the trainee (Saed \& Asgher, 2012). Development refers to the activities that help individuals attain new knowledge or skills that are necessary for their personal growth. All-inclusive training and development programs help trainees to focus on the skills, attitudes, and knowledge that are necessary to achieve goals and to generate competitive advantages for an organization (Peteraf, 1993). Apospori, Nikandrou, Brewster, and Papalexandris (2008) found that training has a significant effect on organizational performance. Subramaniam et al. (2011) argued that training and development could influence the performance of an organization because the skills, knowledge, and abilities of employees could be improved continuously. AL-Qudah, Osman, Ab Halim, and Al-Shatanawi (2014) stated that a significant relationship exists between training and development and organizational performance. Blair (2007) found that investment on training and development could produce huge benefits for an organization. Several researchers have reported that training can positively affect productivity, and employees and employers can receive mutual benefits from training (Conti, 2005; Ballot et al., 2006). A significant relationship between training/development and organizational performance was also established in several studies (Dimba, 2010; Subramaniam et al., 2011; Apospori et al., 2008; Kundu, 2007, ALQudah et al., 2014).

\section{Research hypotheses}

H1: A positive relationship exists between recruitment and selection and organizational performance in Jordanian Public University.

$\mathrm{H} 2$ : A positive relationship exists between training and development and organizational performance in Jordanian Public University.

\section{Research findings}

This study adopted a five-point Likert scale to answer the items in the questionnaire, with 5 denoting "always" and 1 denoting "never." Mean scores less than 2.33 were considered weak, mean scores between 2.76 and 3.94 were considered moderate, and mean scores of more than 3.67 were considered high. Table 1 presents the mean and standard deviations of the items in the survey.

Table 1. Statistical results of the survey

\begin{tabular}{|c|c|c|c|}
\hline Ser. & Items & Mean & $\begin{array}{c}\text { Standard } \\
\text { deviations }\end{array}$ \\
\hline & Recruitment and Selection & & \\
\hline 1 & $\begin{array}{l}\text { The organization practices harmonious (multiple approach) terms and conditions in the } \\
\text { process of recruitment and selection. }\end{array}$ & 3.6993 & 1.08873 \\
\hline 2 & $\begin{array}{l}\text { The organization clearly practices fair treatment in the promotion process for all } \\
\text { employees. }\end{array}$ & 3.5163 & 1.05820 \\
\hline 3 & The organization fills vacancies from within the organization as a norm (promotion). & 3.5686 & 1.09883 \\
\hline 4 & The organization uses multiple test criteria to select the right employees & 3.7059 & 1.08750 \\
\hline \multirow[t]{2}{*}{5} & $\begin{array}{l}\text { The organization selects the right employees based on the multi-skills and experience of } \\
\text { the candidates. }\end{array}$ & 3.4118 & 1.13282 \\
\hline & Training and Development & & \\
\hline 6 & $\begin{array}{l}\text { The organization organizes detailed training programs for the employees in all areas of } \\
\text { quality. }\end{array}$ & 3.5752 & 1.13377 \\
\hline 7 & The organization identifies training needs through a performance appraisal system. & 3.5490 & 1.15816 \\
\hline 8 & $\begin{array}{l}\text { The organization shares new knowledge and skills with employees periodically to improve } \\
\text { the performance. }\end{array}$ & 3.6928 & 1.10192 \\
\hline 9 & $\begin{array}{l}\text { The organization offers me with training opportunities that enable me to exercise my range } \\
\text { of knowledge, skills, and abilities. }\end{array}$ & 3.4052 & 1.09086 \\
\hline 10 & $\begin{array}{l}\text { The organization offers opportunities for employees to discuss the training and } \\
\text { development needs. }\end{array}$ & 3.5229 & 1.15898 \\
\hline
\end{tabular}


Human Resource Management Practices: Influence of recruitment and selection, and training .....

Item 4 obtained the highest mean score (3.70) for the first variable, recruitment and selection (see Table 1). This result suggested that the recruitment and selection processes within the Jordanian Public University are well established. Staff members know the rules and procedures, and have experience and competence in the employee recruitment and selection process. Item 9 obtained the highest mean score (3.69) for the second variable, training and development. This result implied that the training or course content is relevant and applicable to the day-to-day responsibilities of the staff.

Table 2.Correlation analysis

\begin{tabular}{|c|c|c|c|}
\hline Variables & Organizational performance & Recruitment and selection & $\begin{array}{c}\text { Training and } \\
\text { development }\end{array}$ \\
\hline Organizational performance & 1 & .726 & .688 \\
\hline Recruitment and selection & .726 & 1 & .623 \\
\hline Training and development & .688 & .623 & 1 \\
\hline
\end{tabular}

Table 2 indicates that recruitment and selection had the highest correlation value $(\mathrm{r}=.726 ; \mathrm{p}<.05)$, and training and development has the least correlation value $(\mathrm{r}=.688 ; \mathrm{p}<.05)$. The results showed that all the variables have positive relationship and statistically significant $(\mathrm{p}<.05)$.

Table 3.Regression analysis

\begin{tabular}{|c|c|c}
\hline Variables & Beta & Sig. \\
\hline Recruitment and selection & .342 & .000 \\
\hline Training and development & .371 & .000 \\
\hline & R-square $=.355$ & \\
& Durbin Watson $=1.911$ & \\
& Sig. F $=0.000$ & \\
\hline
\end{tabular}

Table 3 presents the multiple regression coefficients $(\beta)$ of the two independent variables to the organizational performance as dependent variable. All variables in HRM practices are significant at $\mathrm{p}<.05$. In terms of beta values, training and development had the highest beta coefficient $($ Beta $=.371)$. This result indicated that training and development variable indicated the strongest contribution to explain the dependent variable (organizational performance). Recruitment and selection had the least beta value (Beta $=.342$ ). $\mathrm{R}$ square value is .355 and Durbin Watson is 1.911.According to Hair et al. (2010), the acceptable value for Durbin Watson is more than 1 and less than 3.

\section{Hypotheses testing} performance.

To test the hypotheses, a simple regression analysis was performed on HRM practices and employee

H1: A positive relationship exists between recruitment and selection and organizational performance in Jordanian Public University.

The effect of recruitment and selection was tested against organizational performance by using regression analysis. The results indicated that a positive and statistically significant relationship exists between the two variables as shown in Table $3(\beta=.342, \mathrm{p}<.05)$. Therefore, $\mathbf{H 1}$ is accepted.

H2: A positive relationship exists between training and development and organizational performance in Jordanian Public University.

The effect of training and development was tested against organizational performance by using regression analysis. The results indicated that a positive and statistically significant relationship exists between the two variables as shown in Table $3(\beta=0.586, \mathrm{p}<.05)$. Therefore, $\mathbf{H} 2$ is accepted.

Table 4.Results of Hypotheses Testing

\begin{tabular}{lll}
\hline Hypotheses & Finding \\
\hline H1 & $\begin{array}{l}\text { A positive relationship exists between recruitment and selection and organizational performance in Jordanian } \\
\text { Public University. }\end{array}$ \\
\hline H2 & $\begin{array}{l}\text { A positive relationship exists between training and development and organizational performance in Jordanian } \\
\text { Public University. }\end{array}$ \\
\hline
\end{tabular}

The results of the hypotheses testing indicated that the independent variables are significantly correlated with the dependent variable. The correlation results confirmed a significant association between the independent and dependent variables. The analysis suggested the lack of multicollinearity in this study because the correlation coefficient is less than 0.80 . Recruitment and selection have a positive relationship with 
Human Resource Management Practices: Influence of recruitment and selection, and training .....

organizational performance. This finding is also supported by other studies (Terpstra \& Rozell, 1993; Harel \& Tzafrir, 1996; Gberevbie, 2010). Training and development have a positive relationship with employee performance. This results are supported by the findings by Dimba (2010), Subramaniam et al. (2011), Apospori et al. (2008), Kundu (2007), and AL-Qudah et al. (2014).

\section{Recommendations}

Human resources, which are considered as the greatest asset of an organization, refer to people whose knowledge, skills, and abilities are utilized to create and to deliver effective services. Effective recruitment and selection attracts the right quality and quantity of people, develops the knowledge, skills, and abilities of employees, and retains employees within the organization. To improve further the system of Jordanian Public University, modern technology should be utilized to plan strategically and to develop HR. Moreover, a training and management development program should be implemented to enhance the capabilities of employees of the Jordanian Public University. Investing in the improvement of the knowledge and skills of employees would enable the university to develop more productive and effective employees.

\section{References}

[1]. AL-Qudah, M. K. M., Osman, A., Ab Halim, M. S., \& Al-Shatanawi, H. A., (2014). The Effect of Human Resources Planning and Training and Development on Organizational Performance in the Government Sector in Jordan, International Journal of Academic Research in Business and Social Sciences, Vol. 4, No. 4.

[2]. Apospori, E., Nikandrou, I., Brewster, C., \& Papalexandris, N. (2008). HRM and Organizational Performance in Northern and Southern Europe, International Journal of Human Resource Management. Vol.19, 7, 1187-1207.

[3]. Arsad, M. (2012). Human Resource Management Practices and Organizational Performance: A Study on Administrators in Universiti Teknologi Mara. (Unpublished MSc Dissertation).Universiti Utara Malaysia.

[4]. Ballot, Gérard, Fakhfakh, F., \&Taymaz, E. (2006). Who benefits from training and R \& D, the firm or the workers? British Journal of Industrial Relations, Vol.44, 473-495.

[5]. Blair, D. \& Sisakhti, R. 2007. "Sales training: what makes it work"? T+D Magazine, August, available at: www.astd.org/astd/Publications/TD_Magazine/2007_pdf/August/0708 ExecSum.htm.Retrieved on 22-2-2014.

[6]. Collins, J.D. and Hitt, M.A. (2006), "Leveraging tacit knowledge in alliances: the importance of using relational capabilities to build and leverage relational capital', Journal of Engineering and Technology Management, Vol. 23 No. 3, pp. $147-67$.

[7]. Conti, G. (2005). Training, Productivity and Wages in Italy. Labour Economics, Vol.12, 557-576.

[8]. De Waal, A. \& Frijns, M. (2011). Longitudinal research into factors of high performance: the follow-up case of Nabil Bank. Measuring Business Excellence, 15(1), 4-19.

[9]. Delaney, J. T. \& Huselid, M. A. (1996). The impact of human resource management practices on perceptions of organizational performance. Academy of Management Journal, 39(4), 949-969.

[10]. Dessler, G. (2007), Human Resource Management, 11th ed., Prentice-Hall, Englewood Cliffs, Dixon, N. M. (1991). Helping US HR professionals into action learning. Action Learning in Practice, 2nd edition. UK: Gower, Eldershot.

[11]. Gberevbie, D.E. (2010). "Strategies for Employee Recruitment, Retention and Performance: Dimension of the Federal Civil Service of Nigeria". African Journal of Business Management.Vol.4 (8).pp.1447-1456.

[12]. Guest, D. E. (1997). Human Resource Management and Performance: review and research agenda. The International Journal of Human Resource Management, 8(3).

[13]. Harel, G.H. \& Tzafrir, S.S. (1996). "The Effects of Human Resource Management Practices on the Perceptions of Organisational and Market Performance of the Firm". Human Resource Management.Vol.38, pp.185-200.

[14]. Huselid, M. A. \& Becker, B. E. (2000). Comment on "Measurement error in research on human resources and firm performance: How much error is there and how does it influence effect size estimates?" by Gerhart, Wright, McMahan and Snell. Personnel Psychology, 53(4), 835-854.

[15]. Kundu, S. M. (2007). Human Resource Management Practices in Insurance Companies Operating in India. Proceedings of the 13th Asia Pacific Management conference, (pp. pp. 472-488). Melbourne, Australia.

[16]. Mathis, H. \& Jackson, L. (2004). Human Resource Management, Singapore",. Thomson Asia Pte . Ltd.

[17]. McCann, J.E. and Buckner, M. (2004), "Strategically integrating knowledge management initiatives", Journal of Knowledge Management, Vol. 8 No. 1, pp. 47-63.

[18]. Pathak, R. D., Budhwar, P. S., Singh, V. \& Hannas, P. (2005). Best HRM practices and employees' psychological outcomes: A study of shipping companies in Cyprus. South Asian Journal of Management, 12(4), 7.

[19]. Pfeffer, J. (1998). Seven practices of successful organizations. California Management Review, 4(2), 96.

[20]. Price, A. (2004). Human Resource Management in a Business Context. (2nd ed). London: Thomson Learning.

[21]. Richard, P. J., Devinney, T. M., Yip, G. S. \& Johnson, G. (2009). Measuring organizational performance: Towards methodological best practice. Journal of Management, 35(3), 718-804.

[22]. Smyth, R., (2004). Exploring the usefulness of a conceptual framework as a research tool: A researcher's reflections. Issues In Educational Research, Vol 14, 2004.

[23]. Steiss, A. W. (2003). Strategic management for public and non-profit organisations. New York: Taylor and Francis Inc.

[24]. Storey, J. (1989). New perspectives on HRM. International Thomson Business Press, UK.

[25]. Subramaniam, C., Shamsudin, F. M. \& Ibrahim, H. (2011). Linking human resource practices and organisational performance: Evidence from small and medium organizations in Malaysia. Jurnal Pengurusan, 32, 27-37.

[26]. Terpstra, D.E. \&Rozell, E.J. (1993). The Relationship of Staffing Practices to Organisational Level Measures of Performance. Personnel Psychology. Vol.46, pp. 27-48.

[27]. Thurbin, P. J. (1994). Implementing the learning organization: The 17th days programme. UK: Pitman Publishing.

[28]. Vlachos, I. P. (2009). The effects of human resource practices on firm growth. International Journal of Business Science and Applied Management, Vol.4 (2), 17-34. 